\title{
Accompanying the Spiritually Wounded: On Human Sinfulness, Responsibility and Culpability
}

Much of the controversy over Amoris Laetitia ${ }^{1}$ has centred on the age-old question in the Church of who is "permitted" to receive Holy Communion and who isn't. Nevertheless, as the general focus of the exhortation on the "gospel of the family" makes evident, this is not Pope Francis' concern in drafting the exhortation, nor is it the raison detre behind the now famous Chapter 8 that presents a pastoral approach of "Accompanying, Discerning and Integrating Weakness" for families in complex situations.

An earlier version of this paper was delivered in Maltese to address the clergy of the Maltese Archdiocese on the occasion of their yearly "aggiornamento" course of formation held at the Archbishop's Seminary, Tal-Virtù, Rabat, June 4-7, 2017. The transcipt of the recording of that talk is available in the proceedings of the gathering published by the Archdiocese of Malta. N. Delicata, L-Att Uman, ir-Responsabbiltà u l-Imputabilità, in: Dixxerniment, Akkumpanjament u Integrazzjoni, Eds. E. Agius, J. Berry, pp. 77-98, Floriana 2018: Archbishop's Curia.

1 Pope Francis, Post-synodal Apostolic Exhortation Amoris Laetitia, March 19, 2016, http://w2.vatican.va/content/dam/francesco/pdf/apost_exhortations/documents/papa-francesco_esortazione-ap_20160319_amoris-laetitia_en.pdf (27.01.2019). 
After all the aim of any pastoral ministry is not the judgement of whether a person is sinful or not (we all are), or whether one should be included or excluded from the Christian community, but something much deeper and complex still. By way of analogy, in medicine it does not suffice to distinguish between those healthy or not. Such a distinction only serves to spearhead the much more complex effort of arriving at a precise diagnosis of the patient's disease, and therefore to diligently seek the most appropriate treatment. Likewise, pastoral care gives much care and attention to the weak, especially those on the brink of death (both metaphorically and literally), in order to offer Christ's healing. But even when a person considers himself or herself to be healthy, until Christ's gift of eternal life, they nonetheless remain fragile and susceptible to illness. Therefore, the more realistic aim of any pastoral care is healing and continuous purification, in order to maintain health. In turn, this implies that the nobler aim of any pastoral care is formation and accompaniment.

The emphasis on formation is not only a subject matter of Amoris Laetitia but also of the Ordo Paenitentiae, promulgated on 2 December 1973, which includes the norms and reformed rites, as demanded by the Second Vatican Council, for the Sacrament of Reconciliation. The document "Rediscovering the Ordo Paenitentiae", presented by the Congregation for Divine Worship and the Discipline of the Sacraments for the Jubilee of Mercy, puts it in this way: "Conversion of heart is not only the principle element; it is also the one which unifies all the acts of the penitent which constitute the Sacrament, given that every single element is defined as leading to conversion of heart."

Amoris Laetitia invites us to rediscover this traditional pastoral "method" which aims not merely to judge (or, to be another's conscience, dictating to them what to do), but to heal. "Healing" is not like a magic pill that purifies the person, instantaneously cleansing them to receive Holy Communion. Rather, "healing" is gradual, where the person who is accompanied by a spiritual companion, confronts himself or herself, recognises and admits their faults and accepts the mercy of God which empowers them to become a "new creation". This is the "key" through which Amoris Laetitia, and in particular Chapter 8, must be interpreted.

2 Congregation for Divine Worship and the Discipline of the Sacraments, "Rediscovering the 'Rite of Penance," 2015/2, http://www.vatican.va/roman_curia/congregations/ ccdds/documents/rc_con_ccdds_notitiae-2015-quaderno-penitenza_en.html (27.01.2019). 
This is evident from Pope Francis' use in the introduction of Amoris Laetitia of the principle: "time is greater than space." 3 This statement was first expounded in Pope Francis' programmatic apostolic exhortation, Evangelii gaudium, ${ }^{4}$ in the context of the reflection on the evangelisation of culture. ${ }^{5}$ The importance of this phrase lies in its challenge to moral theology not to remain "legalistic" in its approach, but to become a process of therapeutic formation.

Accordingly, and in view of the crucial importance of this principle, in the first part of this paper, I will unpack the metaphor "time is greater than space" to suggest pointers for the accompaniment of "penitents." As it highlights the parallelism between the evangelisation of culture, discussed in Evangelii Gaudium, and the accompaniment of families, the subject matter of Amoris Laetitia, this first part will highlight the necessary attitudes and aspirations that the Pope demands for the process of discernment, especially in so-called "irregular" situations.

The second section aims to show the doctrinal continuity, and complementarity, between the more "legalistic" approach of Familiaris Consortio ${ }^{6}$ and the more "therapeutic" approach of Amoris Laetitia's Chapter 8, an approach that aims at "integration" through a process of accompaniment. "Integration" will be presented in two senses: the gradual enlightening of conscience of the penitent, and one's reconciliation with the community. ${ }^{7}$

In the third and final part, I will then contrast the traditional praxis that examines culpability, with the equally traditional praxis of telling and listening to the penitent's life story. Both assume a process of discernment, and are necessary in the process of accompaniment for ongoing conversion.

\footnotetext{
3 Amoris Laetitia 3.

4 Pope Francis, Apostolic Exhortation Evangelii Gaudium, November 24, 2013, http:// w2.vatican.va/content/francesco/en/apost_exhortations/documents/papa-francesco_esortazione-ap_20131124_evangelii-gaudium.html (27.01.2019).

5 Evangelii Gaudium 222-225.

6 Pope John Paul II, Post-synodal Apostolic Exhortation Familiaris Consortio, November 22, 1981, Nr 8, http://w2.vatican.va/content/john-paul-ii/en/apost_exhortations/ documents/hf_jp-ii_exh_19811122_familiaris-consortio.html (27.01.2019).

$7 \quad$ Amoris Laetitia 8.
} 


\section{Evangelisation in an ambiguous moral reality}

For Pope Francis, the metaphor "time is greater than space" implies an important attitude for the evangelisation of culture ${ }^{8}$ as well as for pastoral ministry, including ministry with families (as applied in Chapter 8 of Amoris Laetitia). Both ad intra as well as ad extra, the church must deal with complex issues while being a witness to the Good News. This Good News is the love of God, or as Saint Thomas Aquinas beautifully puts it in his treatise on the virtue of caritas, the "mercy" that God shows to each one of us, especially the most vulnerable, that calls to conversion and to a new life in Christ. Moreover, numerous problems faced by families necessarily mirror those in the culture at large. Thus, one can hardly separate the evangelisation of culture from the evangelisation of families and vice versa. In turn, this suggests that what the Pope teaches about the evangelisation of culture could also shed light about how best to interpret Chapter 8 of Amoris Laetitia. More concretely still, the metaphor "time is greater than space" helps us to unpack what the Pope intends by "to understand, forgive, accompany, hope, and above all integrate" the weak. ${ }^{9}$

In Evangelii Gaudium, the Pope draws two crucial points from the metaphor "time is greater than space" which are also applicable to the morally ambiguous pastoral situations cited in Amoris Laetitia. First, the Pope states: " [T]ime' has to do with fullness as an expression of the horizon which constantly opens before us, while each individual moment has to do with limitation as an expression of enclosure... This principle enables us to work slowly but surely, without being obsessed with immediate results." ${ }^{10}$

In other words, "time" makes the constant acceptance of God's grace possible, while "space" limits the possibility of reception of the fullness of God's grace and its actualisation in one's life. In Chapter 8, the Pope discusses factors, both internal and external to the person, that make us the vulnerable persons we are: for instance, the circumstances which limit our choices and, even more so, that determine our life story. This frailty of character, of will, of understanding and, hence, our sin, limits our freedom to recognise the truth that in turn, is expressed in concrete actions. We must

\footnotetext{
$8 \quad$ Evangelii Gaudium 222-225.

$9 \quad$ Amoris Laetitia 312.

10 Evangelii Gaudium 222-223.
} 
keep on exerting ourselves to grow in virtue and to create more suitable external circumstances. However, this process of change takes time and is always dependent on God's grace. Accompaniment is thus more about sowing seeds that are tended silently by the Lord over a lifetime.

For this reason, in Evangelii Gaudium, Pope Francis cites the German Catholic priest and theologian Romano Guardini to highlight a fundamental principle in the process of spiritual accompaniment, discernment and integration: "The only measure for properly evaluating an age is to ask to what extent it fosters the development and attainment of a full and authentically meaningful human existence, in accordance with the peculiar character and the capacities of that age."11

Because of our human limitations, our evaluation of the progress of a particular culture should not be based on fixed expectations or rigid criteria. It is true that there is an ideal that should always inspire us. But every culture has its proper potential as well as limits that give it its distinct characteristics. Like in the parable of the talents, ${ }^{12}$ the master was as satisfied with the four talents of the one whom he entrusted with two talents as much as he was satisfied with the ten talents of the one whom he entrusted with five talents. The point is not the quantity, but rather the authentic fidelity to the master, as well as the honest and fruitful work to develop fully one's potential in a given moment.

Guardini's principle is also helpful in the process of accompanying families, especially those in irregular situations. The Second Vatican Council emphasised the universal call to holiness, including the holiness of marriage, the sacrament of reciprocal and complete love. This implies, that notwithstanding our limitations, all of us are called to do our utmost in our particular situation. Since, "time is greater than space," in every situation we find ourselves in, we have the interior freedom to accept God's love: not necessarily in a perfect way, but in the most excellent way possible at that moment.

In a medical situation, when the physician makes a diagnosis, he or she does not assume that all patients have the same ailment, or that a particular medicine will always give the same result. Likewise, the Pope stresses the process of accompaniment over a one-size-fits-all solution or "rules", even

\footnotetext{
11 Evangelii Gaudium 224.

12 Cf. Mt 25:14-30.
} 
though there might be certain common elements to most situations. This is how Pope Francis' approach is "realistic" and not "idealistic"13 even in the process of spiritual accompaniment. Thus, in summary, "time is greater than space" demands three principle attitudes from the spiritual director or confessor:

1. Great patience: this process might not only take long, but it depends on the overall disposition of the penitent. Just as the Spirit entices, but never forces, the spiritual director can only support the process and wait patiently;

2. Constant discernment to evaluate whether the penitent is making progress or encountering new stumbling blocks. St Ignatius of Loyola teaches that the criteria of consolation and desolation assist us in discerning the presence of good and evil spirits in one's life. By recognising the movement of spirits in the life of the accompanied person, the spiritual director can be more precise in applying the necessary and appropriate therapy in that particular circumstance;

3. An attitude of great humility, where the spiritual companion as well as the accompanied person become aware and accept that there might be a vast disparity between the good desired and the good that is, in actual fact, attainable at this moment. Still, the person who is being accompanied, must be encouraged so they persist on the right path. Thus one must be grateful for every small step in the power of grace, and this achievement-even if seemingly insignificant-must be celebrated with a spirit of gratitude for the way God works in one's life. Small, regular steps along the spiritual journey empower the person to grow in their personal, as well as communal, process of integration.

This last point is extremely important and must be stressed. The doubts and uneasiness expressed by many about Amoris Laetitia stem precisely from the fact that Pope Francis demands that spiritual mentors be realistic in their expectations of how penitents respond to the Spirit. Being grateful for small steps, even when miles away from the ideal, might come across, especially to those more rigorist in their understanding of morals, as if Pope Francis were "lowering the standards," or as if he were promoting a mentality where anything goes. I believe this fear is uncalled for, and indeed that Pope Francis' intent is quite the opposite.

13 Cf. Evangelii Gaudium 231-233. 
In calling us to be realistic, Pope Francis is, not only teaching us to be patient with the penitent, but more crucially, to not dismiss or underestimate evil, the devil and all his malicious work. As Pope Francis admits when adopting the motto, Miserando atque eligendo, it is precisely as sinners that we are seen by God and chosen.

In order to truly experience God's loving mercy, we have to experience, acutely and viscerally, our state of weakness and acknowledge our true limitations. It is the sick who must be healed, but it is also those who acknowledge their illness that seek medicinal healing. Thus, our limitations are not only a source of sorrow and shame. They are also what stirs us in the depth of our being and disposes us to kneel before the Lord, beg for forgiveness, and be open to receive the grace of his mercy. Paradoxically, it is in our sinful state that we receive God's first gift of recognising our misery and, therefore, of recognising our complete dependence on God as Creator, our sole Saviour and Consoler.

Should we require proof that this "pastoral realism" not only helps the Church in her pastoral ministry, but is also theologically correct, it is sufficient to cite from Chapter 4 of Amoris Laetitia, where Pope Francis reflects on the hymn of love to portray a picture of the nobility of sacramental marriage: "Marriage is a precious sign, for "when a man and a woman celebrate the sacrament of marriage, God is, as it were, 'mirrored' in them; he impresses in them his own features and the indelible character of his love. Marriage is the icon of God's love for us... This has concrete daily consequences, because the spouses, "in virtue of the sacrament, are invested with a true and proper mission..." "We should not however confuse different levels: there is no need to lay upon two limited persons the tremendous burden of having to reproduce perfectly the union existing between Christ and his Church, for marriage as a sign entails «a dynamic process..., one which advances gradually with the progressive integration of the gifts of God» ${ }^{15}$."16

In the process of accompaniment towards conversion and healing, both the spiritual director and penitent must be alert and continuously actively discerning. On the penitent's side this habitus of discernment must include two questions: "what is my sin?" (which implies: what is it that is truly and most vitally limiting me in my journey to God?) and, secondly, "in this

\footnotetext{
14 Amoris Laetitia 121.

Familiaris consortio 9.

Amoris Laetitia 122.
} 
moment, how is God inviting me to grow in his love?" (that is, how is the present horizon of grace unfolding?).

In this process, which is a continuous examen of conscience, the role of the spiritual director is not to act as the conscience of the person, but to help the one entrusted to their care to be better attuned not only to the presence of the Spirit of God urging them to love, but also to the evil spirit, the lying spirit, who darkens their conscience to their true limitations and even potential. In the Ignatian tradition, the spiritual director accompanies the person to discern the spirits through helping them read the truth emerging through their moments of consolation and desolation. This ability is crucial, especially when accompanying people whose life stories have been very challenging, and therefore where it is not only difficult to untangle the complexity of how God might be calling the person at that particular moment, but also to help them be truly in touch with their core sinfulness, "naming" their sin.

\section{Conversion and integration}

The previous section showed how the principle "time is greater than space" is central to the process of conversion and for Christian formation, in their personal as well as social aspects. We have seen how personal discernment, in the context of accompaniment, demands an understanding of how the sinner can open up to the loving mercy of God at every moment, a mercy that not only strengthens us to turn away from sin, but also to grow in our being disciples of Christ.

In this section, I will delve deeper into the dynamics of this discipleship, by showing how this process of accompaniment also implies a process of integration through what Pope John Paul II termed, a "principle of graduality."

Pope Francis draws on the "principle of graduality" to promote a spiritual accompaniment and discernment that bear fruit in an ever deeper conversion and discipleship, which in turn, are expressed in concrete actions. In irregular situations especially, conversion will also be manifested through the ways in which the persons involved try to "regularise" their relationships. However, we must admit, that applying the "principle of graduality" in situations where there appear to be no easy solutions to "regularise" the union or to 
see "immediate results" in pastoral work, is no easy matter. I am referring in particular to cases of separated or divorced people who are now in new relationships, including a new civil marriage. These cases are particularly difficult for the Catholic Church, not only because they are morally complex, but also because the discipline of the Church does not offer clear guidelines or structures how the persons involved can be "integrated" back into the Christian community, in a manner which is clearly understood and accepted by all.

It is in this context that the question, "Father, may I receive Holy Communion?", comes up in its most dramatic and raw expression. The question is not only complex for its theological and spiritual implications, but also because of its profoundly human and symbolic connotations, which would be detrimental for the Church to ignore. For those living in an irregular relationships; and even more so, for those whose relationship cannot be regularised, Holy Communion may be reduced to a mere stamp of exclusion or inclusion.

Thus, it is important that we understand and appreciate, both the difference, and the continuity, between the apostolic exhortation of John Paul II Familiaris Consortio and Amoris Laetitia, and especially between the more 'legalistic' pastoral approach of Familiaris Consortio and the more 'therapeutic' pastoral approach of Amoris Laetitia's Chapter 8. In other words, it is crucial that we reflect on how, while a judge is deemed to be just even when pronouncing a sentence of conviction (and therefore 'exclusion' is a perfectly valid possible option, even for a long time - though the Gospel does not allow the Church to practice it indefinitely without contradicting her raison dêtre), a physician can never abandon the patient (and so, from this perspective, the physician continues to assist the weak and the sinful until they are safely back in the sheepfold). In line with Familiaris Consortio, Amoris Laetitia emphasises the importance of integration: "The logic of integration is the key to their pastoral care, a care which would allow them not only to realise that they belong to the Church as the body of Christ, but also to know that they can have a joyful and fruitful experience in it. They are baptised; they are brothers and sisters; the Holy Spirit pours into their hearts gifts and talents for the good of all. Their participation can be expressed in different ecclesial services, which necessarily requires discerning which of 
the various forms of exclusion currently practised in the liturgical, pastoral, educational and institutional framework, can be surmounted."17

These are moving words. However, the crux of the matter is that we need to acknowledge that the progress of integration within the Christian community itself should also reflect the process of conversion of heart, and therefore, of one's personal integration which bears fruit. In the first centuries of the Church, this dynamic was particularly evident through the "public" nature of the "order of penitents". However, throughout the centuries, this important link between personal repentance and being reconciled with the community weakened when the pastoral care of the sinner became a more "private" affair and, eventually, increasingly confined to the secrecy of the confessional. Today, we have a widespread crisis in marriages that leads to many more "irregular" situations that are well-known in their communities. Therefore, it is understandable that one of the main problems we are facing today is not only how to accompany persons in the foro interno, but also, when conversion and growth starts to happen in the intimacy of the process of accompaniment, how to provide concrete ways of participating in ecclesial life, thus enabling persons in complex situations to be re-integrated in the community. This is a concern since, while it is necessary and crucial that persons on the journey of healing should no longer feel 'excluded' in their communities, as Amoris Laetitia continues to note, notwithstanding the authenticity of their process of repentance, they can continue to be seen as "objectively contradicting" the Christian ideal.

This is the continuity found between Familiaris Consortio 84 and Chapter 8 of Amoris Laetitia. But it is also the point which provides seed for a 'new' pastoral approach. Familiaris Consortio 84 and Chapter 8 of Amoris Laetitia agree perfectly on the two fundamental theological points: both propose a pastoral care based on the principle of graduality ${ }^{18}$ and both consolidate the Christian ideal of marriage. The new seed is found in Amoris Laetitia which says: "If we consider the immense variety of concrete situations such as those I have mentioned, it is understandable that neither the Synod nor this Exhortation could be expected to provide a new set of general rules, canonical in nature and applicable to all cases. What is possible is simply a renewed encouragement to undertake a responsible personal and pastoral

\footnotetext{
$17 \quad$ Amoris Laetitia 299.

18 Familiaris Consortio 34.
} 
discernment of particular cases, one which would recognise that, since "the degree of responsibility is not equal in all cases", the consequences or effects of a rule need not necessarily always be the same."19

While Familiaris Consortio 84 exhorts: "Pastors must know that, for the sake of truth, they are obliged to exercise careful discernment of situations... However, the Church reaffirms her practice, which is based upon Sacred Scripture, of not admitting to Eucharistic Communion divorced persons who have remarried. They are unable to be admitted thereto from the fact that their state and condition of life objectively contradict that union of love between Christ and the Church which is signified and effected by the Eucharist. Besides this, there is another special pastoral reason: if these people were admitted to the Eucharist, the faithful would be led into error and confusion regarding the Church's teaching about the indissolubility of marriage." ${ }^{20}$

Familiaris Consortio 84 suggests concrete methods of integration even by making "exceptions" to its own rule. (I have in mind its "pastoral solution" that the divorced and remarried live "as brother and sister.") But Amoris Laetitia refuses to convey any hard rules and, instead, it insists on the need for a process of ongoing discernment that not only considers each case on its own merit, but demands that every Shepherd examines and proposes all the fitting paths of integration in their own dioceses and pastoral contexts. This is not a sign of the Church becoming relativist (as some criticise), but because every pastoral situation, every person in every parish and every diocese, all have their own dynamic of spiritual growth which needs to be taken into account. Integration is not something abstract and does not take place in a vacuum.

The new "terminology" of Amoris Laetitia is, after all, respectful of the sinodality of the Church in her recognition that, while the Church is one, holy, catholic and apostolic, there is diversity of communities and cultural contexts. Perhaps in some ecclesial communities Amoris Laetitia opens a door for more obvious and visible inclusion; in many other churches - as Cardinal Schönborn suggests - it might suggest the opposite need of greater caution, as every ecclesial community seeks "right judgement on those

19 Amoris Laetitia 300. This is also the case with regard to sacramental discipline, since through discernment one can acknowledge that in a particular situation no grave fault exists. In such cases, what is found in another document applies. Cf. Evangelii Gaudium (24 November 2013), 44 and 47.

20 Familiaris Consortio 84. 
things which are hindering the possibility of a fuller share in the life of the Church."

Amoris Laetitia is, in no way, stating that the only way of integrating those living in irregular situations is through their full participation in the Eucharist (and hence their risking becoming a scandal). But, Amoris Laetitia argues for the deeper reality that, while some people might be living in irregular situations that are a far cry from the Christian ideal of marriage, they might not be necessarily culpable, or fully culpable, of their situation, and therefore not necessarily contradicting in their hearts the grace of God. As Amoris Laetitia 302 says: "a negative judgment about an objective situation does not imply a judgment about the imputability or culpability of the person involved."21 It would thus also follow that they might not necessarily have to exclude themselves from Holy Eucharist. This is more so when the context in which these people may receive the Holy Eucharist might not lead to much confusion or scandal.

The process of integration ultimately has two aspects - the interior aspect of one's relationship with God, and the communitarian aspect with the ecclesia - and the tragedy is that these two do not always reflect each other in a transparent manner. This will always be a tension in the Church that is the responsibility of the local Bishop to tend to: the good of the individual penitent and the common good of the ecclesial community.

\section{Sin and culpability}

In this final section, the article will focus on the personal integration of the wounded person, as God confronts him or her in their heart. Here we must remember the Church's traditional teaching on sin, particularly the important distinction between mortal and venial sin and, therefore, between a sin whereby the person excludes grace and puts themselves in a position where they cannot participate in the communal Eucharistic Meal without confession and absolution, and that of a person who though committing sins, remains open to grace; indeed, the Eucharist in itself is for them the much needed medicine for healing in the process of discipleship.

$21 \quad$ Amoris Laetitia 302. 
The Catechism of the Catholic Church ${ }^{22}$ describes mortal sin in this manner: "Mortal sin destroys charity in the heart of man by a grave violation of God's law; it turns man away from God, who is his ultimate end and his beatitude, by preferring an inferior good to him."23 "For a sin to be mortal, three conditions must together be met: 'Mortal sin is sin whose object is grave matter and which is also committed with full knowledge and deliberate consent." 24

In other words, mortal sin separates the person from God's grace and from the ecclesial community because it is "a radical possibility of human freedom... for our freedom has the power to make choices for ever, with no turning back" (1861). The choice of mortal sin is a "human act", which means a "free act" that is an expression, even though contradictory, of the dignity of the human being, created in the image and likeness of God. As the Catechism puts it: "Freedom is the power, rooted in reason and will, to act or not to act, to do this or that, and so to perform deliberate actions on one's own responsibility. By free will one shapes one's own life. (1731) ... This freedom characterises properly human acts. It is the basis of praise or blame, merit or reproach" (1732).

This implies, as the Catechism says, that "when [one] disobeys the moral law in a grave matter, but without full knowledge or without complete consent" $^{25}$ - that is, without an expression of that fullness of freedom by which the person disposes himself or herself, and therefore becomes responsible for his or her own actions - we cannot regard the action a mortal sin but a venial $\sin .$. that is a sin that "does not break the covenant with God."26

A person can perform an objectively wrong action, but if such an action is not the result of human will, or if one does not understand the true and full moral meaning of one's actions, the person cannot be considered fully responsible for the evil committed; and if one is not fully responsible, then one is not considered culpable, or entirely culpable either. ${ }^{27}$ In other words:

\footnotetext{
22 Catechism of the Catholic Church, (Libreria Editrice Vaticana, Città del Vaticano, 1993); http://www.vatican.va/archive/ENG0015/_INDEX.HTM (27.01.2019).

23 Catechism of the Catholic Church 1855.

24 Catechism of the Catholic Church 1857.

25 Catechism of the Catholic Church 1862.

26 Catechism of the Catholic Church 1863.

27 Human freedom only finds its culmination in what the human being is created for: God himself. As the Catechism 1733 says: "The more one does what is good, the freer one
} 
"Freedom makes man responsible for his acts to the extent that they are voluntary. Progress in virtue, knowledge of the good, and ascesis enhance the mastery of the will over its acts." ${ }^{28}$

This shows clearly how the tradition understands freedom as "freedom for" and not just as "freedom to choose". Human freedom finds its telos in God alone; therefore, by its very nature, any form of sin that distances the person from God enslaves a person, predisposing them to be even less free to break a vicious cycle of decline. Thus, for the person to exercise fully their freedom, they need the virtues, especially the infused virtues to perfect the natural faculties of the human person - emotions, will and reason. The contrary, however, is also true for vice: any form of vice, any imperfection in emotion, in the will, in reason, in the person's character, hinders the person from acting freely and, therefore, responsibly. The person becomes a victim of one's own past, of one's own mistakes, of one's own circumstances that continue to burden him or her.

But, since there are numerous factors that hinder one's free exercise of the will as expressed in one's concrete actions, tradition also considers how this lack of freedom also diminishes our responsibility. Thus, these factors need to be considered in the judgement of imputability and thus in the discernment of the position of that person in God's eyes: "Imputability and responsibility for an action can be diminished or even nullified by ignorance, inadvertence, duress, fear, habit, inordinate attachments, and other psychological or social factors."29

We must also not ignore the maxim that "time is greater than space." This is a crucial principle in any kind of pastoral care and especially in complex ones where, because of various circumstances, it is not always possible to do all the desired good without committing greater harm. For this reason Amoris Laetitia insists: "The Church possesses a solid body of reflection concerning mitigating factors and situations. Hence it can no longer simply be said that all those in any "irregular" situation are living in a state of mortal

becomes. There is no true freedom except in the service of what is good and just. The choice to disobey and do evil is an abuse of freedom and leads to "the slavery of sin". See Rm 6, 17.

Here we see that mortal sin, that action which symbolises the denial of God, implies freedom, and therefore is not crippled under any sin or its effect.

This leads to what the Catechism says on our responsibility as human beings, that we are created free and, in fact, we are judged to be guilty or not according to our doings."

28 Catechism of the Catholic Church 1734.

29 Catechism of the Catholic Church 1735. 
sin and are deprived of sanctifying grace. More is involved here than mere ignorance of the rule. A subject may know full well the rule, yet have great difficulty in understanding "its inherent values", or be in a concrete situation which does not allow him or her to act differently and decide otherwise without further sin." 30

This emphasis on the discernment of culpability, or its mitigation, even in an objectively wrong situation, is a way of how Amoris Laetitia Chapter 8 is not only in conformity with the established magisterial teaching of the Church, that sees the relation of the sinner with God through the lens of judgement, but also honours the experience of the human person who, in his or her conscience, feels qualms and sorrow when confronted by their own sinfulness. However, the experience of guilt should always be seen in a larger context: the loving mercy of God. Evaluating culpability is helpful in the accompaniment of persons who are either still in denial about their culpability or exaggerate their guilt because of psychological factors. This useful tool for the confessor or spiritual companion is a means for how to reach the more precise diagnosis of the spiritual situation of the person in front of God. For, as Amoris Laetitia points out: "Because of forms of conditioning and mitigating factors, it is possible that in an objective situation of sin - which may not be subjectively culpable, or fully such a person can be living in God's grace, can love and can also grow in the life of grace and charity, while receiving the Church's help to this end." ${ }^{31}$

It should also be emphasised that when a language that stresses too much "measuring" the culpability of a situation is taken outside the wider "therapeutic" context, it may also become problematic, even absurd - as the Jesuit moralist James Keenan puts it ${ }^{32}$ - since we might end up having many objective "sins" or wrongdoings without anyone being able, strictly speaking,

30 Amoris Laetitia 301.

31 In certain cases, this can include the help of the sacraments. Hence, "I want to remind priests that the confessional must not be a torture chamber, but rather an encounter with the Lord's mercy" (Apostolic Exhortation Evangelii Gaudium [24 November 2013], 44. I would also point out that the Eucharist "is not a prize for the perfect, but a powerful medicine and nourishment for the weak" (Evangelii Gaudium 47). See also Amoris laetitia 305.

32 The important distinction between "objectively grave matter" and "subjective non-culpability" was often used in the confessional "not simply to absolve confessing laity," but even "to dissolve them of any guilt in the first place." James F. Keenan, A History of Catholic Moral Theology in the Twentieth Century: From Confessing Sins to Liberating Consciences, London-New York 2010: Continuum, pp. 148-149. 
to take full responsibility for them. Without responsibility culpability is lessened, which therefore, renders one not in need to contemplate God's mercy. But this is a great danger of pastoral ministry, since without a clear sense of sin, one also diminishes their sense of Divine Mercy and, therefore, their spiritual sense of God desiring to heal them and sanctify them. Without the sense of God's grace, the human person cannot fully reach their fullness. The same holds true if instead of "lessened-culpability for sin" we speak only of "problems" of an affective or psychological nature arising from childhood trauma or deprivation, cultural habits, etc. Slowly the erosion of the faculty of will in a person reduces the human being to little more than a programmed puppet.

Apart from the consideration of the subjective culpability of individual sins, it is also important to consider the story behind that sin, the narrative which the person presents, precisely to understand better what the true source of the guilt is and how the salient aspects of the person's moral experience are interpreted.

In this context, we are in fact reminded of the third criterion for considering a sin to be mortal: that its object be grave matter. But, we need to keep in mind that the object of the moral act is in itself a judgement of the conscience of the person who committed that act. As both the Catechism and Veritatis Splendor 78 point out: "The object chosen is a good toward which the will deliberately directs itself. It is the matter of a human act. The object chosen morally specifies the act of the will, insofar as reason recognises and judges it to be or not to be in conformity with the true good. Objective norms of morality express the rational order of good and evil, attested to by conscience." 33 And: "The morality of the human act depends primarily and fundamentally on the "object" rationally chosen by the deliberate will, as is borne out by the insightful analysis, still valid today, made by Saint Thomas. ${ }^{34}$ In order to be able to grasp the object of an act which specifies that act morally, it is therefore necessary to place oneself in the perspective of the acting person. The object of the act of willing is in fact a freely chosen kind of behaviour. To the extent that it is in conformity with the order of reason, it is the cause of the goodness of the will; it perfects us morally, and disposes us to recognise our ultimate end in the perfect good, primordial love. By the

\footnotetext{
33 Catechism of the Catholic Church 1751; Veritatis Splendor 78.

34 See Thomas Aquinas, Summa Theologiae, I-II, q. 18, a. 6.
} 
object of a given moral act, then, one cannot mean a process or an event of the merely physical order, to be assessed on the basis of its ability to bring about a given state of affairs in the outside world. Rather, that object is the proximate end of a deliberate decision which determines the act of willing on the part of the acting person." 35

Particular attention is to be given to the way how the accompanied person shares their story; some assistance from the spiritual companion is helpful in at least two aspects: it helps the accompanied person to manifest their conscience for a truly "integral confession", and secondly, it sheds crucial light on the true spiritual reality of the person in front of God. In narrating their whole story, the person does not simply portray their version of "what happened," but also indicates how their moral choices were made within the limitations of their conscience, and therefore, of their understanding and will. Although these choices might not have been the best possible choices, they still shed important light on the healing necessary for the person, precisely in those areas of their life that they are still misjudging or are blind about.

In the process of telling their whole story, the penitent is invited to integrate their woundedness, by making a more truthful and honest discernment of the object of their moral act and therefore, also of the seriousness of their sins - even if in the beginning, the person might have been blind, or was trying to shirk their responsibility and culpability for the act. In other words, the penitent becomes more aware of their sins. The more a person can take responsibility for recognising the truth about themselves in their own conscience, the more the person becomes capable of taking better decisions in their circumstances and situation. As Pope Francis says: " $[\mathrm{C}]$ onscience can do more than recognise that a given situation does not correspond objectively to the overall demands of the Gospel. It can also recognise with sincerity and honesty what for now is the most generous response which can be given to God, and come to see with a certain moral security that it is what God himself is asking amid the concrete complexity of one's limits, while yet not fully the objective ideal. In any event, let us recall that this discernment is dynamic; it must remain ever open to new

35 Veritatis Splendor 78. I elaborate this point further in: N. Delicata, Amoris Laetitia and Veritatis Splendor on the Object of the Act, "Melita Theologica" 67 no. 2 (2017), pp. 237-265. 
stages of growth and to new decisions which can enable the ideal to be more fully realised." 36

\section{Conclusion}

The integration of persons who up to now have been excluded on account of their complex situations demands a process of personal discernment and of ecclesial accompaniment in the presence of God. What is my sin? What is God calling me for? How is my sin hindering me from answering to God's calling? This process requires great patience and humility, especially in those moments where the penitent and the one accompanying the person become more aware of limitations which are difficult or impossible to overcome - at least for the time being. But we should remember that God's grace is mostly seen in the dark, in the depths of one's own conscience where the person becomes aware of their vulnerability and weakness and is able to allow themselves to be embraced completely by the loving mercy of God. When this happens, there arises in the person a new creative impulse towards renewal and it is there that the seed of accompaniment bears much fruit.

\section{Bibliography}

Catechism of the Catholic Church, (Libreria Editrice Vaticana, Città del Vaticano, 1993, http://www.vatican.va/archive/ENG0015/_INDEX.HTM (27.01.2019).

Congregation for Divine Worship and the Discipline of the Sacraments, "Rediscovering the 'Rite of Penance," 2015/2, http://www.vatican.va/ roman_curia/congregations/ccdds/documents/rc_con_ccdds_notitiae2015-quaderno-penitenza_en.html (27.01.2019).

Delicata N., Amoris Laetitia and Veritatis Splendor on the Object of the Act, "Melita Theologica" 67 no. 2 (2017), pp. 237-265.

\footnotetext{
$36 \quad$ Amoris Laetitia 303.
} 
Delicata N., L-Att Uman, ir-Responsabbiltà u l-Imputabilità, in: Dixxerniment, Akkumpanjament u Integrazzjoni, Eds. E. Agius, J. Berry, pp. 7798, Floriana 2018: Archbishop's Curia.

Keenan J.F., A History of Catholic Moral Theology in the Twentieth Century: From Confessing Sins to Liberating Consciences, London-New York 2010: Continuum, pp. 148-149.

Pope Francis, Apostolic Exhortation Evangelii Gaudium, November 24, 2013, http://w2.vatican.va/content/francesco/en/apost_exhortations/documents/papa-francesco_esortazione-ap_20131124_evangelii-gaudium. html (27.01.2019).

Pope Francis, Post-synodal Apostolic Exhortation Amoris Laetitia, March 19, 2016, http://w2.vatican.va/content/dam/francesco/pdf/apost_exhortations/documents/papa-francesco_esortazione-ap_20160319_amoris-laetitia_en.pdf (27.01.2019).

Pope John Paul II, Post-synodal Apostolic Exhortation Familiaris Consortio, November 22, 1981, $\mathrm{Nr}$ 8, http://w2.vatican.va/content/john-paul-ii/ en/apost_exhortations/documents/hf_jp-ii_exh_19811122_familiarisconsortio.html (27.01.2019).

Thomas Aquinas, Summa Theologiae, I-II, q. 18, a. 6. 
